Torben Kragh Grodal

\title{
Arbejds-lyst eller Back to the Future
}

Visuelle studier i Reagan-Amerika

Reagan-æraen går på hæld. Det der tegnede til at blive en nyindspilning i farver af USA's storhedstid, 1950'erne, med grandpa Reagan i rollen som John Wayne, tegner nu mere og mere til at blive et studie i leverplettet alderdomssvækkelse og traumernes genkomst. Efter Watergate's aktive skurkeri kommer Irangate som udtryk for den aldrende skuespillers passive medvirken i en dilettantisk B-film. Forsøget på at genskabe efterkrigstidens globale økonomiske dominans førte til at USA omkring 1985 for første gang siden l. verdenskrig blev en debitornation. Forsøget på at genoplive månelandingseuforien førte til Challenger-katastrofen. Intet er dog så symbolsk for the American way of life som Detroit-dollargrinet, der nu er en døende art, - dét kom særlig symbolsk til udtryk, da GM, i et desperat forsøg på at forbedre imaget for årtiers amerikanske drøm, Cadillac'en, lod italienere designe og producere en serie karosserier i bedste euro-styling; de bliver nu fløjet til Detroit hvor de forsynes med motor og indmad (herunder formodentlig benzinindsprøjtningssystemer og blokeringsfri bremser fra Bosch). Ingen amerikansk drøm er p.t. stærkere end at tjene tilstrækkeligt med dollars til en Mercedes eller en BMW. I en TVreklame for Nova, et GM-produkt i den billigere ende, vises i lidt sløret fotografering en bilfabrik hvor arbejderne arbejder efter 'japansk recept' med indledende kollektiv gymnastik og kvalitetscirkler; også underlægningsmusikken er japansk, så seeren må tro at man bevidner en japansk produktion af billig kvalitet, indtil det afsleres at det faktisk er en GM-fabrik i Californien der med amerikanske arbejdere laver ligeså gode og billige produkter som japanerne. Reaganoprustningen tog flere og flere aldrende krigsskibe ud af mølposen for at sende dem ud på de syv verdenshave og vise Stars and Stripes. Når de stævner ud gennem Golden Gates evige oceangus kan de møde en højsøflåde for indadgående: tungtlastede civile transportskibe hvorpå der med kæmpebogstaver står TOYOTA, HONDA, NISSAN, 
MAZDA og HUONDAI, eller Maersk Line's containerskibe lastede med sydøstasiatisk elektronik, fra chips til walkmen og fjernsyn.

Mange forskere har set Hollywood-filmen og dens efterfolgere indenfor fjernsynsfiktionen som udstillingsvinduer for en integreret USimperialisme, hvor reklamen for the American way of life var en platform for salg af amerikanske produkter (Cola-kulturen) og integreret hermed et forsvar for USA's militære herredømme. I det tidsrum mellem l. verdenskrig og indtil slutningen af 1960'erne hvor USA var den ubestridte altdominerende leder af verdens moderniseringsproces, var det vanskeligt, for ikke at sige umuligt at skelne mellem modernisering og amerikanisering. Derfor var samtidig internationalisering primært identisk med 'amerikanisering', forestået af de amerikanske multinationale foretagender og via USA's leadership i de overnationale organisationer, fra NATO til en række FN-organisationer.

Men firserne, Reagan-æraen, har for alvor betydet et gennembrud for en centrumsløs internationalisering og modernisering. Om man kører i amerikanske eller udenlandske biler i serier som Dallas og Dynasty afhænger af hvilken bilfabrik der på det givne tidspunkt betaler mest til TV-producenten for product placement. I TV-reklamerne udspilles en daglig kamp mellem alverdens produkter. Mens amerikanske biler, som vi så, bl.a. sælges til japansk musik, sælges japanske biler, f.eks. inden for fritidsbilsmarkedet, med en hyper-mytologiskamerikansk indpakning. Gammelamerikansk udseende blondiner opfordrer til at købe amerikansk, og i næste spot zippes lynlåsen med ærefrygt og lyst ned på en tøjindhyllet BMW. På vejene dukker de forste forsigtige skilte med $\mathrm{km}$-angivelser op under miles-angivelserne, og små svedige amerikanske børn kæmper med at regne med $\mathrm{cm}$, $\mathrm{kg}$ og gram.

Den konservative Reagan-rus var baseret på forestillingerne om en genoplivning af de gode gamle amerikanske værdier, af the entrepreneureal spirit, iværksætterånden, den lille selvstændiges foretagsomhed, hvor små $h i$-tech-firmaer havde erstattet familiebruget som rammen om en fri individualisme. Small is Beautiful. Silicon Valley blev en ny amerikansk myte: det hyperintellektuelle husmandsbrug i vækst; og indbegrebet af denne myte var Apple Computer's Davidskamp med Goliath'en IBM. Med introduktionen af den lille, personlige computer, hvis logo er det regnbuefarvede æble, hvoraf der er taget en bid, og hvis karakteristikon er den lille grå 'mus' til styringen af operationerne, rettedes et alvorligt stød mod de storindustrielle mainframecomputers, der var beregnet til store, hierarkiske arbejdspladser og processer. En ny, menneskelig, dvs. småborgerlig teknik, - der dog 
som sin forudsætning havde de milliarder af dollars som den amerikanske stat og krigsindustri havde investeret i udviklingen af microchip'en til brug i raketter og rumfartøjer: Iværksætterånden sættes hele tiden i relief på en baggrund af storforetagender.

Den teknologiske innovation gav også arbejde til håndens arbejdere, men mest i Sydøstasien, hvor orientalske kvindeøjne overvågede chipsproduktionen for en slik. Mens de nye veluddannede grupper kunne vejre morgenluft og ekspandere, betød udviklingen for de traditionelle blue collar-grupper at de tendentielt blev inddraget $i$ en konkurrence med alverdens andre ikke-faglærte. Og de kunne ikke som tidligere generationer af håndens arbejdere gå mod vest og realisere den småborgerlige drøm ved at inddrage ny og jomfruelig jord, eftersom det nu var i 'himlen', i åndens verden, og ikke på jorden at de jomfruelige, småborgerlige territorier var beliggende.

I en verden, hvor verdens intellekter kæmper med og mod hinanden, og hvor hvede og oksekød rådner op på overskudslagre, er westernmytologiens dyrkelse af jorden og grænsen, the frontier, en tyndslidt metafor. Fra en marginalposition er science fiction-genren kommet ind i det ideologiske centrum med George Lucas' Star Wars. I et grænseløst rum, befolket af personer med sære, uangelsaksiske navne, udkæmpes kampe på lasersværd, westernpistolen er udskiftet med et teknisk opdateret samuraisværd. Vor tids 'husmandsbrug' lejer sig ind i nicher i glasfunklende, himmelstræbende skattely i Boston, Tokyo og Milano. Helikopter-og jet-ruter, satelitter og kabler forbinder disse centre med langt stærkere bånd end den tilfældige geografiske nærhed mellem et slumkvarter og et kontortårn. Tilsvarende er tiden (historien og evolutionen) i de moderne rumepos'er blevet til rum, space, hvori man kan pendle mellem højtudviklede samfund afbrudt af turistikke afstikkere til territoriebundne sociale urformer. De nye intellektuelle husmænd - designeren, computereksperten, biotechtroldmanden - er nærmere at ligne med vandrende riddere, der med jævne mellemrum udskifter deres lensherrer, de multinationale. Jorden og nationalismen er for bønder og fattiglemmer, lensherrer og vasaller rejser og dyster i det internationale rum.

Pessimistiske versioner af denne udvikling kan man se i film som Ridley Scott's Blade Runner (1982) og Carpenters Flugtaktion New York (1981), hvor pjalteproletarisering og hi tech indgår i et mere eller mindre tvangsmæssigt samliv. Vi ser ikke flertallet, forstadsamerika, for hvem robotfabrikkerne betyder mere konsum, men kun storbyghetto'er. I Scott-filmen huser isolerede arkaisk-futuristiske pyramider og tårne den kontrollerende tekniske intelligens vis-a-vis det omgivende hav af pjalteproletarer og robotter (læs fremmedgjorte lønar- 
bejdere), teknikken er kun overvågning. I Carpenterfilmen er storbyghettoen - New York - helt konkret afspærret fra omverdenen. Den måde, hvorpå underudviklingen vil leve $\mathrm{i}$ porerne af det rige samfund, tegner imidlertid til at blive langt mindre spektakulær. Det kræver forbløffende lidt direkte magt at adskille det velhavende flertal fra de store lommer af underudvikling og fattigdom.

\section{Magtudøvelse, (post)industri og volds fiktion}

Reaganismens konservative drøm om retableringen af et småborgerligt, foretagsomt Amerika er både blevet en succes og en fiasko. De store foretagender er ikke så meget blevet svækket af konkurrencen med de små, nye, som af konkurrencen med udenlandske storforetagender. Grundlaget for at styrke småborgerligheden på bekostning af storforetagende og lønarbejde er yderligere blevet svækket ved den blanding af succes og fiasko som den småborgerlige konservatisme har haft $\mathrm{i}$ forhold til dens erklærede mål om at få staten til at visne bort. Reagan blev bl.a. valgt på et antiwashington-program: ned med de offentlige udgifter. Når man ser Porscherne rulle henover hullede veje, ser de forfaldne og overfyld te skoler, elimineringen af ansatserne til et socialt velfærdssystem osv., må man sige at kampen har været en succes. De offentlige udgifter har dog ikke været faldende, fordi oprustningen har taget, hvad nedskæringen i de civile programmer har frisat. Oprustningen har kraftigt styrket 'militærsocialismen', den militær-industrielle kæmpesektor af storforetagender, hvor markedskræfterne delvis er sat ud af spil. Her foregår over halvdelen af landets forskning, hvorved der frembringes ny og avanceret teknologi som japanere og europæere derefter kan benytte til civile formål. De mest konkurrencedygtige dele af den amerikanske industri - fly- og computerindustri - er opstået i randen af 'militærsocialismen'. Forfaldet i den civile del af staten medfører en dekvalificering og marginalisering af store dele af den potentielle arbejdsstyrke, der så kan få stolthed og identitet ved at identificere sig med imperiets, nationens evne til at fore Star Wars. I en række henseender er science fictiongenren i den amerikanske udgave en ideologisk-fantasimæssig overbygning på det militær-industrielle kompleks. Ironisk nok har en indæd kritiker af dette, Stanley Kubrick, ved sin parodiske bearbejdning af Air-Force-krigsfilm i Dr. Strangelove og ved sin 2001 - A Space Odyssey, medvirket til den moderne udformning af genren.

I en science-fiction-gyserfilm som Alien II (1986) får man et uskønt 
billede af hvorledes taberne, de dårligt uddannede amerikanere, integreres som lejesoldater i et højteknologisk USA's krig mod en diffus kosmisk 'fjende'. Uskønheden er imidlertid moralsk, for intetsteds dyrkes det visuelt sublime mere end i SF-filmene. En af denne genres sublime klichéer er billedet af et kæmperumskib, fotograferet nedefra, således at det, når det tyst sejler fremad mod fjerne mål, fremviser en teknik, et produkt af social kooperation, der overvælder enkeltindividet. Kun i det himmelske giver USA's oprustning mening, selv med begrænset viden og fantasi er det evident, at denne jord kun for den selvmorderiske har dimensioner til at udkæmpe en sublim krig mod et Evil Empire. Og kun i det himmelske kan man forsvare at foretage den totale mobilisering af enkeltindividet, den totalte suspendering af privatliv og fritid til fordel for en 'nationalsocialistisk', krigerisk arbejdsetos. De pjalteproletarer der i Alien II disciplineres til arbejde og social indordning forekommer endda svært unyttige; industri- og krigsrobotter kunne have gjort et bedre arbejde billigere. Rummet er først og fremmest intellektualismens og synssansens sfære; kropslighed, nærsanslighed, er et fremmedelement. Som metropolernes himmelstræbende glastårne således er rumskibet og rumstationen primært arbejdspladser for funktionærer, beskæftiget med overvågning og interpersonel beherskelse. Ridley Scott's Alien (1979), artikulerede netop primært de nye socialgruppers socialpsykologiske problematik, og det mislykkede i Alien II's forsøg på at indplante den 'gammeldags' krigsfilms hovedsageligt proletariske verden i de himmelske omgivelser kan man opfatte som et vidnesbyrd om kropsarbejdets krise og marginalisering.

Livet i det private erhvervsliv, på den private arbejdsplads, skildres sjældent på amerikansk film (undtagen i de småborgerlige 'truckerfilm'). Tidligere var det krigsfilmen der dannede rammen om skildringen af enkeltindividets indordning $\mathrm{i}$ og modstand mod den store hierarkiske arbejdsplads. $\mathrm{Nu}$ er det mere politi-film og science-fiction-film, bl.a. på grund af den omtalte sociale forskydning henimod et funktionærsamfund. Egentlig er det påfaldende at et så privatkapitalistisk samfund i den grad skildrer sig i den offentlige sektors billede. Endnu mere påfaldende at beskrivelsen af de gigantiske industrielle produktivkræfter har form af en fascineret beskrivelse af beherskelsesinstrumenter: tanks, fly, raketter, helikoptere, krigsrumskib, med bilen og lastbilen som de markante civile undtagelser, selvom det også her hyppigt er politibilen, bilen som instrument til social beherskelse, der beskrives. Intet er så markant i nyere amerikansk film i forhold til f.eks. danske som den stadige, fetich-agtige skildring af disse industriprodukter. I nærbilleder af instrument-pa- 
neler og styre-aggregater bindes tilskuerens subjektivitet ind i identifikationen med den kollektive udfoldelse. I udvendige helhedsbilleder skildres den dynamiske, tingslige fylde.

Denne stadige fremvisning af sociale beherskelsesinstrumenter og beherskelsessituationer kan give udlændingen falske forestillinger om graden af sociale spændinger og krigerisk aggression i USA. I nok så høj grad skal de ses i sammenhæng med forlystelsesindustriens og reklameindustriens ligeså hektiske påkaldelse af lyst og selvudfoldelse. Modsætningen mellem arbejde, social beherskelse osv. og fritidslyst, varesamfundets uendelige fristelser, støder langt mere uformidlet sammen i USA end i Danmark. Man kan forestille sig den ansatte på en større (f .eks. militær-industriel) virksomhed, der ved ankomsten møder de bevæbnede vagter, viser identifikation etc., arbejder $\mathrm{i}$ en atmosfære af stadig økonomisk kalkulation og teknisk overvågning, og som, når vedkommende forlader arbejdspladsen i sin bil straks via bilradioen er indfanget i salgs-og-lyst-artikulationens endeløse strøm, der senere forlænges af vejsidens reklamer og forretninger, og i intimsfæren forstærkes af tv-reklamer. I krigs-, action- og politifilmene kan lønarbejderne lystfyldt identificere sig som subjekter såvel med overvågning og disciplin som med den sociale potens. Ved denne arbejds- og dydsmoralisering midt i fritidsforlystelsen har disse genrer karakter af formidling mellem privatmenneske-forbruger og samfundsborger-lønarbejder. Voldstematiseringen er forsøg på en stadig fortætning af id og overjeg, af lyst og overvågning, rettet udad i den voldelige omverdensbeherskelse. Amerikas rolle som verdens politibetjent har således en sær forbindelse med hele konstitueringen af amerikaneren som borger og arbejdende i og med den symbolske rolle den nationale magtudøvelse har i fremstillingen af arbejdsetos og samfundsborgerlighed. 1970erne miskrediterede på mange planer denne helhed (-Vietnam, den nye bevidsthed om den etniske pluralisme, den forstærkede lokalisme, de øverste lags internationalisme) og en filmisk genoplivning af en koldkrigerisk nationalisme har haft begrænset grobund, hvad vi skal vende tilbage til. Det har primært været politifilmene med deres budskab om lov-og-orden, arbejdsetos og individuelt initiativ, og actionsfilmenes jongleren med de industrielle produkter, der har formidlet mellem lyst og arbejde.

For et flertal af befolkningen har Reagans budskab om en foretagsomhedens ånd kun kunnet udmønte sig i budskabet om et forstærket krav om arbejdsomhed indenfor hierarkiske rammer. Nedlæggelsen af ungdomsoprørsånden fra 1960'erne er en nedtoning af privat- og fritidsverdenen til fordel for arbejdsverdenen. Stillet overfor truslen om en nedgang i levestandarden i forlængelse af oliekriser m.v. valgte 
hovedparten af den stemmende befolkning understregningen af arbejdet på bekostning af tematiseringen af fritidsverdenens frihed. Den følelse af socialt sammenbrud der herskede i midthalvfjerdserne i forlangelse af oliekrise og vietnamnederlag, og som kom til udtryk i disse år store katastrofefilm, gav ikke anledning til nogen revolutionære lyster, men tværtimod til en defensiv bevægelse mod de traditionelle værdier. For de unge og intellektuelle var tanken om at være hippie-agtige lumpensammlere i kanten af et potentielt fattigt samfund betydeligt mindre tiltrækkende end at være lumpensammlere i kanten af et rigt samfund. Fra folkeskole til universitet er kravene om præstation skærpet voldsomt, i et stigende krav om 'excellence'. Opløsningen af kærnefamilien var særlig urealiserbar i et samfund med en så rudimentær socialforsorg og offentlig børneforsorg som det amerikanske. Og som tidligere påpeget er det især for de intellektuelt arbejdende lettere àt opbygge småborgerlige nicher indenfor et hierarkisk samfund. Jo mere produktionen blev videnskabeliggjort, des mere rykkede disse grupper socialt frem. Silicon Valley er i en række henseender et legitimt barn af Standford-universitetet og det militært-industrielle kompleks. Det er derfor paradoksalt at den film, der om nogen synes at være udtryk for Reagan-militarismen, Rambo, samtidig har et dybt konfliktfyldt forhold til centrale dele af denne krigeriske teknik. I det efterfølgende vil vi eftersøge de sociale rødder til dette tilsyneladende paradoks.

\section{Dolkestødet mod En Amerikansk Arbejderkrop}

Efter The Western kom der spaghetti-western, efter John Wayne og hans grønne baretter kom Sylvester Stallone. At det skulle blive en blanding af Jesus, Tarzan og Che Guevara der skulle gøre retfærdiggørelse af Vietnamkrigen til en kassesucces kan forekomme paradoksalt, men viser noget om det voldsomme symbolske arbejde der har været nødvendigt. Og er samtidig et vidnesbyrd om de indre-amerikanske spændinger der forsøges udladet i et ydre rum.

Sylvester Stallone er først og fremmest en kroppens mand, forbundet med proletariske og pjalteproletariske livssamhængé. Allerede i hans forste kassesucces, Rocky, fra 1976, bliver han eksponeret for det ikke-intellektuelle Amerika. Mere pjalte-proletar end proletar, for han er helt adskilt fra produktionslivet, ghettoiseret i forfaldent slum. I en næsten samtidig film, Convoy (1978, baseret på en McCloudepisode fra 1976) kan man se en skildring af stolte kropsarbejdere, 
truckers, der føler stolthed ved deres arbejde, deres guddommelige, kromskinnende kæmpelastbiler og deres biltelefoner. De benytter deres herredømme over produktionsmidlerne til oprør mod undertrykkere (politiet); i deres småborgerlige virkelighedsforståelse er de kontrollerende myndigheder hovedfjenden. Rocky derimod har kun sin krop, en snart halvgammel bokserkrop, som han enten kan sælge til tilfældige fjerderangskampe eller mod betaling stille til rådighed for en mafiamands indkradsning af ågerlån. Filmen bruger syvtommersøm for at understrege, at Rockys situation er et symbolsk udtryk for hvordan middle America har mistet kontakten med the American dream og med de amerikanske idealer, og den udpensler Philadelphias trøstesløse slum. Fremstillingen er næsten kulturradikal: Alternativet til Rockys bumseliv - det ufaglærte lønarbejde - skildres gennem hans ven, der har fået arbejdsskader af det daglige slid med slagtede dyrekroppe i et frysehus' sibiriske kulde. En sort boksechampion, Apollo Creed, beslutter som en klam kommerciel fidus at fejre 200-året for den amerikanske revolution ved at give en mr. Nobody, en anonym bokser, chancen for at kæmpe mod sig, give ham en chance for at realisere den amerikanske drøm, og valget falder på Rocky. På sæt og vis er dette bare det korrupte big business' hvervning af Rocky til at deltage i rotteræset som bankekød; bokseringen er et billede af den amerikanske darwinistiske alles kamp mod alle. Men til trods for at Rocky møder de amerikanske idealer i kommercialiseret og korrumperet form, giver de hans liv et nyt indhold; han begynder en målrettet træning, og løbetræningen bringer ham fysisk ud af slummet, op til nogle regeringsbygninger der repræsenterer de sande, 200 år gamle amerikanske idealer. Du kan, hvis du bare selv vil! Rocky gør det umulige, han kæmper alle 15 runder, championen vinder kun på points; men Rocky er så forslået, blindet og blodig som en nyfødt eller som den korsfastede Jesus, at han må skrige efter sin pige og hendes dulmende Madonna-kærtegn.

I mytologien om amerikansk arbejdermandighed har der altid indgået et Hell's Angels-aspekt; mandighed betyder evne til at udholde overmenneskelige kropslige lidelser. Men næsten altid som en gennemgangsfase til sejr. Med Stallone-figuren foretages der imidlertid en 'katolsk' skærpelse af dyrkelsen af den blodige, lidelsesfulde 'død'. Hans overkrop er hyppigt blottet, men blottelsens erotiske elementer afbalanceres hele tiden ved at den er et forspil til lidelse og pinsel; helvedets luer kan ved enhver given anledning slikke om denne krop, hvis lidelsesfulde udøvelse af mandighed skriger til himlen om en frelsende Madonna. Macho-kisme kunne man kalde fænomenet. Figuren arbejder hele tiden på kanten af total fornægtelse af den ameri- 
kanske drøm, der jo drejer sig om dennesidig, materiel succes, - en fornægtelse der er i slægt med ayatollaens indvielse af Allahs martyrer eller fascismens dyrkelse af blodet og døden.

'Katolicismen' har selvfølgelig en nærliggende baggrund i det forhold at den amerikanske arbejderklasse i stigende grad består af katolikker; til de traditionelle italienske, irske og polske elementer kommer en stadigt voksende flod af latinamerikanske indvandrere. Men den har også sin forklaring i en øget marginalisering af den før så stolte gruppe af organiserede blue collar-arbejdere. En stigende konkurrence fra ulande og nyindustrialiserede lande kombineret med en stigende automatisering og robotisering og en stigende vægtning af højteknologi har forskudt den sociale balance. Ikke i form af en pludselig og radikal ændring, men som en kontinuerlig vigen i forhold til funktionærgrupperne, og en mere flydende overgang til pjalteproletariatet og til de nye lavindkomst-servicegrupper. Svingninger mellem fascistoid voldsdyrkelse og 'katolsk' dyrkelse af døden og nederlaget er derfor mere udtryk for lags og klassers tendentielle marginalisering i forhold til den amerikanske drøm end udtryk for samfundshelhedens.

Western- og krigsfilm sammenflettede hyldesten til det kropslige 'arbejde' med kønsrollen: pistol, gevær og næve stod både for varktøj og for fallos. Funktionærernes fremmarch har i de sidste årtier været integreret med kvindernes fremmarch på arbejdsmarkedet, og forskellige politifilms stadigt hyppigere fremstilling af 'falliske' pistolskydende kvinder, er vidnesbyrd om en begyndende opløsning af den mytiske sammenvæuning af kønsrolle og socialrolle. Selvom arbejdermanden og hans omgivelsers kønsrollepraksis og opfattelser måske ikke har ændret sig radikalt, er mulighederne for at forstærke en social-identitet $\mathrm{i}$ en kønsrolleidentitet formindsket $\mathrm{i}$ de senere årtier. Mere måske endda i medie-verdenens symbolfabrikker, fordi producenterne tenderer til at bøje fremstillingerne i retning af deres eget mellemlaglige standpunkt. I Rocky-filmen har sanseligheden tilsvarende vanskeligere ved at udkrystallisere sig i forhold til en kvinde; sammenlignet med westerns m.v. er den homoseksuelle og sadomasochistiske binding til den anden mand langt mere fremtrædende - kvinden artikulerer de ømme rørelser, hvorimod sanseligheden selvhaderisk er projiceret mod den anden mand.

De fascistiske overtoner bliver klarere når man kommer ind i Reaganæraen med de to Rambo-film First Blod (1982) og Rambo (1985). Rambo er grøn baret og Vietnam-veteran, en person der helt har hengivet sig til fædrelandet, men de tapre soldater får et dolkestød $\mathrm{i}$ ryggen af civilister og bureaukrater m.v. Legtimeringen af dolke- 
stødslegenden sker med raffinerede forskydninger og intertekstualiteter. Nogle år efter Vietnamkrigen flakker Rambo rundt i USA's nordvestlige hjørne. Som omflakker og langhåret ligner han mest af alt en hippie, og hans latino-ansigt minder mindst af alt om angelsaksisk mandighed. En lokal politichef giver ham da også samme behandling som 20 år tidligere kunne blive hippierne til del i det amerikanske sydøst; han arresterer ham for omstrejferi og beordrer ham klippet og vasket. Ved flashbacks sammenkædes denne politibrutalitet med kommunisternes tortering af Rambo under krigen. Selvom det senere viser sig at han er en fantastisk soldat, finder han sig langt hen ad vejen i behandlingen som en anden arresteret fredsdemonstrant. Han flygter næsten nøgen ud i den isnende natur, forfulgt først af de lokale politistyrker, senere suppleret med hjemmeværnet. Hans krig mod de forfølgende myndigheder får karakter af guerillakrig, han er Tarzan, indianer og vietcong $\mathrm{i}$ ét ( $\mathrm{i}$ del 2 får vi endda at vide, at han er af indiansk-tysk herkomst). Men, understreges det hele tiden, det er ikke 'hippien', men derimod den veltrænede soldat som alle disse civilister, der ikke har kendt krigen og døden, hader og forfølger. Det rigtige militær, i skikkelse af 'den gode fader', Rambos tidligere træner og oberst, kommer til stede for at beskytte civilisterne mod 'sønnens' hævn og for at hjælpe ham, men 'den onde fader', politichefen, vil i forblindet had til 'sønnen' (med den store fallos-kniv og den bare, frysende overkrop) ikke sit eget bedste. Og slutteligt kommer straffen over det civile samfunds Sodoma. Som en hævnende engel destruerer Rambo den lille bys kommercielle, reklameoplyste centrum og skyder den onde civilist/politichef, for så at bryde sammen i gråd ved militær-'faderens' skulder.

Fejhed, civilisme, lyst og civilisation stilles overfor mod, militær og natur i volds-martyren Rambos viethed til vold, lidelse og 'død'. Rambo har en næsten psykotisk følelsesdeformering, og hans talefærdigheder minder til tider om et treårigt barns. Tilskueren opfordres både til medlidenhed med hans psykiske beskadigelse og til beundring for hans arkaiske voldsudøvelse. At der psykoanalytisk er tale om en voldsom fastholdelse af et ødipalt oprør er evident og udgør en vigtig del af filmens verdensappel til et ungdommeligt, mandligt publikum. Men Rambo er samtidig en fremragende 'specialarbejder' eller 'faglært arbejder', hvis kvalifikationer samfundet ikke mere har brug for. FØR (i 'Vietnam') blev han højt estimeret og dekoreret, $\mathrm{NU}$ er der ikke mere brug for hans kvalifikationer og krop, han er kun et uroelement. Filmen havde premiere i 1982, på et tidspunkt hvor mandefaldet i de traditionelle industrier nåede rekordhøjder og nationalproduktet direkte faldt, mens højtuddannede og folk i nye indu- 
strier allerede havde fået forsmag på de 'gode' tider. Vietnamproblematikken er således også vehikel for bearbejdning af voldsomme indreamerikanske sociale spændinger. John Waynes bagland af arbejdere og småfarmere, der kunne føle sig som middle class eller på vej dertil, er i firserne truet af at blive spaltet i grupper på vej mod funktionærliv og grupper på vej ned i en stadigt voksende 'restgruppe'.

Da den anden Rambo-film havde premiere i 1985 var de økonomiske og politiske konjunkturer vendt: skattelettelse og oprustning havde bragt millioner $\mathrm{i}$ arbejde, Reagan forsegte at genindspille koldkrigen med taler om Sovjetunionen som The Evil Empire. Det er derfor næsten for oplagt at også Rambo må komme $i$ arbejde igen, og at aggressionerne nu forsøges rettet udad, mod USA's fjender. Rambo hyres til en hemmelig mission i Vietnam og befries derfor fra sit arbejde som straffefange $i$ et stenbrud. Men det viser sig snart at den indreamerikanske dolkestødslegende og de indreamerikanske spændinger stadigvæk er nok så betydningsfulde. Skurken er denne gang chefen for en amerikansk lyttepost i Thailand, indbegrebet af en defaitistisk, internationalistisk bureaukrat. Han er omgivet af for millionvis af dollars af det $h i$-tech elektroniske udstyr, der for de højtuddannede udgør Amerikas stolthed og fremtid. Men i denne film er det tværtimod et udtryk for den bureaukratiske sofistikering, der forråder de amerikanske 'drenge', dengang såvel som nu. Selvom stationschefen 'véd' at der stadigvæk er en masse amerikanske soldater i vietnamesiske fangelejre, vil han og hans overordnede (bureaukrater og 'politikere') ikke have det frem, fordi det kan forhindre den internationale afspænding. Rambos hemmelige recognoscering skal tjene til at berolige offentligheden, der kræver at få de savnede drenge hjem, idet stationschefen håber på at han enten bliver dræbt eller ikke finder nogen fanger. Og allerede da Rambo skal kastes ned over Vietnam er han ved at blive dræbt af alt det udstyr, han prakkes på; det hænger fast i flyet, således at han er ved at blive 'kvalt i fødslen' og kun med møje får skåret sig fri af 'navlesnoren'. Med hjælp fra en vietnamesisk pige, der drømmer om at komme til USA og leve "the easy life « lykkes det imidlertid Rambo at finde amerikanske soldater i uhyggelige fangelejre, underkastet barbarisk tortur, befri én, og bringe ham med til opsamlingsstedet.

Men nu udspilles dolkestødslegenden for fuldeste udblæsning. Da bureaukraten hører at Rambo har bevis for kommunisternes ondskab, beordrer han helikopteren tilbage. Rambo og krigsfangen, der er skarpt forfulgt af vietnamesere, ser den amerikanske redningshelikopter vende om for næsen af dem. Judas har forrådt ham og nu 
følger korsfæstelsen. Med tætte billedmæssige lån fra den katolske ikonografi ser vi Stallone ophængt ved armene i en pøl af svineurin, underkastet tortur og elektrochok af røde, russisk-blonde djævle. Ingen tvivl om at russerne står for et asiatisk barbari af værste skuffe, et helvede på jorden. Men Rambo's 'genopstandelse' som krigsgud kommer da russerne meddeler ham den præcise ordlyd af den forrædderiske tilbagekaldelse af helikopteren og da han efterfølgende bryder sin tavshed ved over radioen at true stationschefen på livet. Med den vietnamesiske jomfrus hjælp undviger han, men hun lider snart døden for sin barmhjertigheds- og kærlighedsgerning. Nu kan Vietnamkrigen med dens napalm, helikoptergunships og guerillakrig genspilles, blot med vietnamesere og russere $\mathrm{i}$ amerikanernes rolle som bærere af den dødbringende teknik og med Rambo i guerilla-rollen. Sådan! Ud af dette flammende helvede bringer Rambo en ladning forhutlede amerikanske krigsfanger til den frie verden i en erobret russisk helikopter.

Klimaks indfinder sig da Rambo med blottet overkrop, med et skærf af patroner, tømmer sit maskingevær ind i stationens computerog elektronikpark der totalsmadres, hvorefter stationschefen med et kvælergreb tvinges ned på et bord og Rambos store falliske kniv (som vi tidligere har set ham 'lege' med) suser ned, kun millimeter fra chefens krop. Det populistiske budskab og dets homoseksuelle latens er ikke til at gå fejl af: hovedfjenden er de teknokrater, bureaukrater og politikere, der forråder folkets sag - dem der styres af gusten fornuft, beregning og dollars, ikke af krop og følelse. Kommunisterne er papirtigre i forhold til tekno-bureaukraterne. En håndfuld ramboer kunne sikkert klare hele Sovjet, hvis ikke de blev forrådt af civilister, intellektuelle etc.

En fortsættelse ad denne vej synes dog mindre fremkommelig, med mindre man ville gå ind i en mere eksplicit fascistoid oprørskhed med basis i tabernes Amerika. Selvom den patriotisme, der vælder ud af Rambo's sluttale - »Jeg ønsker at Amerika skal elske os (veteranerne) ligeså meget som vi elsker det « - følelsesmæssigt er i slægt med begrundelsen for Star Wars-Amerika, er der en afgrund mellem ham og de titusindvis af forskere i militærets hi tech laboratorier, der konkret forsøger at producere Star Wars. I Stallones næste film, Cobra (1986) havde han da også en langt mere traditionel, og langt mere systemintegreret rolle som selvtægtsbetjent $\mathbf{i}$ bedste højreorienterede Clint Eastwood/Dirty Harry-stil. Crime is a disease, I'm the cure, proklamerer Stallone når han foretager sine Endlösungs-nedplafninger og rydder op i de problemer som bløde, liberale og intellektuelle politifolk skaber. Lidt patetisk er derfor forsøget på at forøge de sociale 
identifikationsmuligheder ved at funktionær-fernisere hans proletariske overflade, som når han f.eks. forsynes med en PC'er i ungkarlelejligheden, til trods for at han taler et sprog der kun sporadisk vidner om en videregående uddannelse efter børnehaveklassen.

I modsætning til tidligere er der hverken politisk eller økonomisk baggrund for en offensiv amerikansk imperialisme. Reagan-oprustningen er i den forstand koldkrigen gentaget som farce. Med USA som debitornation og med stadigt svindende oversøiske investeringer er der ikke stærke økonomiske kræfter der modvirker neoisolationisme. Og som den amerikanske kapital ønsker sine dollars hjem, således ønsker den amerikanske befolkning sine drenge hjem, selvom de undtagelsesvis giver opretteforestillinger for udvalgte fjender (Libyen, Grenada, Nicaragua og tilsvarende militære sværvægtere) og for de hjemlige Six O'clock News. Billedet af et totalt kommunistisk angreb er blevet erstattet af paranoia over én omverden, der opleves som gidsler for diffuse terroristorganisationer, som truer med at opløse den frie verden. En film som Delta Force (1986) om USA's antiterrorkorps, der redder »American lives« er det nærmeste man kommer til en genoplivning af rollen som verdens politibetjent. Og også denne film handler om at 'redde ofre' fra omverdenens helvede. Kan USA ikke tilbyde sine borgere en tilstrækkelig socialforsorg, kan det i det mindste tilbyde dem militær ambulancetjeneste når de bliver fanget $\mathrm{i}$ udenlandske helveder.

\section{Urscener og himmelsk sublimering}

Den amerikanske filmforsker James Monaco har betegnet den første Rocky-film som en nostalgi-film, fordi dens nedslidte østkyst-arbejdermiljø ganske vist formelt er henlagt til 1970erne, men reelt peger bagud mod 1950erne. Selvom dette måske er lidt af en ønskedrøm, er det evident at der er langt fra Philadelphia-slummen til det forstadsvestkyst-miljø, der danner basis for de mere fremtidsvendte film. At publikum heldigvis mere ønsker at se en Silicon Valley-fremtid end populistisk-imperialistisk vold kan man måske læse ud af det faktum at Spielberg-filmen Back to the Future og ikke Rambo blev den mest sete film i USA i Reagan-æraens jubelår 1985 (begge optaget i det objektive jubelår 1984), før underskud, Challenger og Irangate satte lus i skindpelsen. Den henvender sig direkte til unge lige før og i gymnasiet, filmindustriens kærnepublikum, med et fremadrettet, positivt budskab. Den indgår i den række af ny ungdomsfilm som især 


\section{Spielberg, George Lucas og John Badham har lavet.}

Før en nærmere omtale af disse film er det imidlertid værd at gøre et par bemærkninger om netop den amerikanske skoleungdoms livsvilkår. Som for de voksne er livet artikuleret i en dobbelthed af arbejde (skolegang) og fritid. Set med danske øjne er det offentlige amerikanske skolevæsen både meget autoritært og meget nedslidt, som store dele af resten af den ikke-militære offentlige sektor. En demokratisering i forlængelse af ungdomsoprør m.v. slog kun meget begrænset igennem, og Reagan-æraen har under mottoet Excellence in Youth strammet det elitære konkurrencepræg. Ønsket om raceintegration medførte at man i 1960erne løsrev den offentlige skole fra nærsamfundet; sparsommelighed medforer at klassekvotienter på 35 mere er normen end undtagelsen. Præstationssortering mellem parallelklasser modvirker integrationen. Talløse prøver, karaktergivninger og hjemmearbejde, kombineret med et vist terperi i en række fag forstærker konkurrence- og overvågningspræget. Dertil kommer udbredt brug af sanktionssystemer som eftersidning og bortvisning. Denne individualistiske, konkurrenceprægede, nedslidte og stærkt autoritære atmosfære står i grel kontrast til den sociale overflade der møder ungdommen udenfor skolen. Her tilbyder TV-programmer og TV-reklamer en egalitær og lystbetonet verden. Den gamle, patriarkalske familie er blødgjort og er ikke på samme måde som tidligere en forskole til den lange march gennem det hierarkiske samfund.

For Freud var den ødipale rivalisering et centralt omdrejningspunkt for den menneskelige psyke. Forudsætningen for at denne kan etableres er imidlertid at der eksisterer komplette kernefamilier indenfor hvilke en sådan rivalisering kan udspille sig. Karakteristisk for familielivet fra slutningen af 1950 'erne og fremefter har imidlertid været at talløse kærnefamilier er blevet opløst, og hyppigt opløst på tidspunkter hvor barnet skulle opgive sine besætninger af den ene forælder til fordel for en identificering med den anden og dennes adfærd - f.eks. opgive det direkte begær efter moderen til fordel for en identifikation med faderen og dennes begær af moderen. Det er hyppigt blevet sagt om amerikansk films p.t. ukronede konge, Steven Spielberg, at han mere gik efter action, overflade og teknik end efter psykologi. Men hvis man kigger hans film igennem vil man hurtigt opdage at de har et intenst psykologisk center omkring bearbejdningen af den ødipale problematik og den moderne kærnefamilies problemer. Disse er ganske vist ikke fremstillet 'psykologisk', men derimod skildret og bearbejdet symbolsk. Filmene er dermed indgribende i forhold til en yderst central problemstilling i det moderne USA: (re)formuleringen af familiens roller og disses placering som formid- 
lingsled mellem individ og samfund. Men også i sig selv udtryk for den stigende rolle film og TV har i opfyldningen af de roller som tidligere blev indoptaget direkte; roller og familie indsocialiseres og bearbejdes så at sige 'i filmhistorien'. Spielbergs helt personlige baggrund er samtidig tidstypisk: Han oplevede selv forældrenes skilsmisse samtidig med sin indtræden i puberteten. Forældrenes voldsomme konflikter før skilsmissen forsøgte han at bearbejde bl.a. ved at filme voldsomme handlinger $i$ sin modeltogverden.

Socialt opfatter Spielberg sig meget bevidst som repræsentant for det ikke-fattige middle America, suburbia's, forstædernes talerør og kritiker. Faderen var computerekspert, moderen brugte megen af sin tid til at spille klaver, og vi skal senere se hans forsøg på at forsone teknik og kunst, den faderlige og den moderlige arv. Han voksede samtidig op i en mindre by i Arizona omgivet af fast-food-restauranter, fjernsyn og 'Disney'-film. Først efter gymnasiet mødte han for alvor filmhistorien, f.eks. den europæiske 'kunstfilm'; den amerikanske og den europæiske arv forsøger han meget bevidst at forbinde i en slags 'popart' ved at forme de amerikanske 'trivia', burger- og cola-kulturens produkter (som elektrikeren i Close Encounter of the Third Kind, der skulpturerer sæbeskum, affald osv. til symboler på det sublime).

Det er ikke tilfældigt at Spielbergs første biograffilm Sugarland Express (1974) netop handlede om hvordan en familie i opløsning forsøger en fortvivlet kamp for forening. Filmens stemning er Bonny and Clyde-præget, men i direkte modsætning til dennes anarkistiske frigørelsestema sigter Spielberg mod selvkontrol. En ung fader er i fængsel, og da barnet bliver taget fra moderen for at blive bortadopteret, overtaler hun ham til at flygte fra fængslet og stjæle barnet tilbage. Actionfilmens normale voldsomme modsætning mellem individ og samfund udspilles her i modsætningen mellem familie og myndigheder, og i fremstilling af en flertydig 'skyldsplacering': på den ene side har forældrene mistet barnet, faderen er kommet i fængsel osv., p.gr.a. manglende driftkontrol, selvkontrol, på den anden side forenes familien ved at projicere de indre anomalier ud i et modsætningsforhold til det samfund der har produceret den lille familie. I praktisk taget alle Spielbergs senere film er forholdet individ-samfund sammenvæuet med forholdet individ-familie.

I Spielbergs gennembrudsfilm Jaws sammenvæves rolleproblematik med forestillinger om hvad der er blevet af den amerikanske arv (ligesom i Rocky). Filmen udspiller sig symbolsk omkring USA's nationaldag, d. 4.juli, og har som Rocky et undertema omkring kommercialiseringen af det amerikanske samfund, men her koblet til en 
kritik af ungdomskulturens lystudfoldelse. Filmen udvikler sig snart til en manddomsindvielse, hvor to mellemlaglige mænd lærer at acceptere kastrationen, overvinder dødsfrygten vis-a-vis de feminine gab, ved at identificere sig med Den anden Mand.

Kritikken af kommercialismen udspiller sig i filmen omkring myndighedernes og de mindre erhvervsdrivendes modstand mod at lukke strandene da en kæmpehaj begynder at spise af badegæsterne. Men traditionen tro forandres dette problem til et spørgsmål om den mandlige kønsrolle. Lystprincip og kastrationsangst overfor det faste mandige »a man's got to do what a man's got to do «. Filmen indledes da også i ungdomskulturen: Unge studenter holder party på en natlig strand, med stoffer og spiritus. I denne 'samfundsopløsende' stemning er det kvinderne der har initiativet: en ung fuldmoden kvinde løber med æggende latter ned mod havet mens hun smider tøjet, og svømmer ud. Hendes ven forsøger at holde trit, men han er for afkræftet af spiritus m.v. og falder impotent om i vandkanten, uden at være i stand til at tage tøjet af. Liderligheden har imidlertid sin straf, snart er den unge pige fortæret fra brystet og nedad af den store haj. Det er imidlertid sidste gang i den film at hajen æder kvinder, ligesom der i denne scene heller ikke - som i de senere - ses blod. Der er derfor god grund til at se fortæringen ikke som en straf, men tværtimod som en 'opgåen' $\mathrm{i}$ den store kvindelige-aktive vagina dentataseksualitet. For kampen mod hajen er en kamp for mænd og en kamp for at beskytte drengebørn.

Men det mandlige princip er i en elendig forfatning. Den primært ansvarlige, stedets politichef, er flygtet fra New York til det stille landlige sted for at finde fred, og idyllen med konen er ikke uden undertoner af hendes utilfredshed med hans latente skvattethed, der mest eksplicit kommer til udtryk i hans patologiske vandskrak, angst for omgivethed. Politichefen er svag overfor borgmester m.v. og får snart en ligeså skvattet 'medhjælper', en rigtig mellemlaglig hajekspert med skæg og briller (men dog uden lilla ble), der får kvalme ved blod, indvolde, kropsligt indre. En dreng og en ung mand spises af det forfærdelige gab mens politimand og hajekspert er magtesløse, og politichefens søn har fået chok ved næsten at være blevet spist. Altsammen sker på baggrund af en hektisk badestemning, bart kød, polymorf perversitet.

De to uheldige helte, der får kvalme ved synet af indvolde og blod, må gennemgå en egentlig indvielse til manddommen. Denne gives af en rigtig gammeldags MAND, en gammel sømand og hajfisker, der kan synge om de hjulbenede spanske piger og om nødvendigheden af at forlade kvinderne til fordel for de mandlige pligter. De tre drager 
ud på jagt efter hajen, godt forsynet med falliske instrumenter; de to lærer at yde og lyde, at binde knob, at acceptere de blodige indvolde etc. Et højdepunkt i mandsindvielsen kommer, da sømand og forsker i en pause i kampen konkurrerer om hvem der kan fremvise flest ar og mærker af den bidende og sårende anden på deres udhængende lemmer, arme og ben. Ar fremvises, og de lægger deres arrede ben overkors. Den ene trumfer: en pige har givet ham et »Broken Heart «, den anden overtrumfer med en historie om død, atombomben og hajer. De to mellemlagsmænd har nadveragtigt og symbolsk indoptaget den proletariske mandighed. De besidder til gengæld den sociale potens; den proletariske mandighed er ved sin mangel på social beherskelse socialt overlevet, og efter at have overgivet sin mandighed til mellemlagene bliver den gamle sømand fortæret af hajen. Haj-forskeren forsøger en passiv-aktiv omgang med 'Dentata', lader sig hejse ned i et stålbur for, efter at have leget passiv madding, at placere en stor giftsprøjte i den grumme sprække, men han taber sprøjten. Politichefen er nu helt på toppen, kyler en stor fallisk metalcylinder med komprimeret luft ind i gabet, og skyder derefter hul i cylinderen, så gabet sprænges. Hvorefter de to mandige mellemlaglige mænd i spejlende tosomhed kan svømme ind mod kysten.

Spielberg er vel bevidst om at det han laver er en pastiche, der hyppigt ikke er langt fra parodien (og iøvrigt er filmen hans eneste rigtige bestillingsarbejde). Den proletariske mandighed, som de to mellemlagsmænd lærer af, har mere sit sted i sørøverromaner/film o.l., end i den sociale virkelighed. Spændingen og kampen kommer bl.a. i stand ved at den gamle bevidst forhindrer hjælp fra det moderne, organiserede, teknologiske samfund, for at skabe myte. Men myten skal bruges til at bearbejde det 'feminine' fritidssamfund, de bare kroppe på stranden, den tilhørende kommercialisme (køb og salg af kroppe) og ungdomskulturens ekstreme, promiskuøse udgave heraf. Patriarkalsk arbejdsetos, kropsafgræsning, individualistisk ansvarlighed m.v. er nødvendig for at genskabe et bedre Amerika. Modsat Rambo lærer de to mænd at aflevere deres lille konkrete 'dolk' for at få del i en langt større, symbolsk social 'dolk'.

Spielberg bearbejder den familiære og ødipale konflikt ikke ved realistisk personskildring, men ved at forskyde og bearbejde den i symbolsk-mytiske former hentet fra horror- og science-fiction-film, hvilket har fået mange kritikere til at stå helt uforstående overfor filmenes handling og betydning. Således hævder James Monaco i American Film Now om Spielbergs første 'personlige' storsucces, Close Encounters of the Third Kind $(1977,2$. udg. 1980) at filmens deltemaer ikke hænger 
særlig meget sammen med det 'tynde' hovedplot. F.eks. er en mareridtscene effektjagende: "Scary! So what, if it's pointless in terms of plot! [...] The plot is shot through with false deads, gaping holes, and circuitous side trails, as a number of critics have noted « (s. 178). Hvad er det dog for "gaping holes« der gennemvæver Close Encounters of the Third Kind? Filmen har adskillige planer: l. plan er samfundets, $i$ to underskikkelser: som videnskab-æstetik og som ren magt i form af politi, militær og misbrugt teknik. 2. En mere 'from' ulandsverden. 3. En familie-verden og 4. Det overnaturlige, de mennesker fra rummet, der griber ind i den menneskelige verden. Overfor det menneskelige plan er Rumfolkene 'den store anden' i forhold til hvilken den menneskelige problematik udspiller sig.

For at komme på sporet af denne kan man starte i de scener der artikulerer det private og intime liv. Efter scener der beskriver den sociale myndighed, f.eks. flyledere med dataskærme, hvis rationelle beherskelse konfronteres med det overnaturlige og sublime, skildres elendigheden i Middle Americas's familieliv. To underscener. Først den enlige mor, Jillian Guiler, og hendes lille søn. Tilsyneladende p.gr.a. ufo-erne sker der mærkelige ting i hjemmet, hvad der fascinerer den 3-4 årige søn stærkt, giver ham skinnende øjne. Der er kommet en mærkelig og ufo(r)klarlig kraft ind i hjemmet. Mens moderen sover mærker den lille søn den uregerlige kraft, der får legetøjet til at opføre sig med en skræmmende vildskab. Enhver hjemlig orden nedbrydes, madvarer vælter ud af køleskabet, cola-dåser tømmes kaotisk svinende, vi er i en polymorf-pervers verden. Drengen har legetøj der symboliserer orden, f.eks. en politibil med blinkende lys, men den farer vildt og uhæmmet ind under den sovende moders seng, besat af kraften. Drengen løber ud for at finde kraften, moderen vågner og løber efter ham. Der klippes nu til en anden kaotisk Middle Americascene. Her er drengen væentlig ældre, han anmoder faderen om hjæelp til brøkregning, men faderen, Neary, er streng og undertrykkende, vil tvinge drengen til at lære brøkdelens hemmelighed: han sætter et legetøjstog i gang hvorefter drengen så skal flytte en togvogn en brøkdel. Drengen når det ikke, der kommer uorden, afsporing (voldelig driftudfoldelse). Hele kærnefamilien er nu i opløsning; en mindre dreng står i en kravlegård og smadrer underlivet af en pigedukke mod kanten; moder og fader geråder i strid og skænderi; faderen er autoritær, moderen påståelig. Scenen afbrydes da faderen, der er ansat som el-montør, kaldes ud, fordi ufoerne er ved at true samfundet med el-blackout.

Ufoerne er således forbundet med kærnefamiliens problemer - den lille drengs voldsomme fantasiverden vis-a-vis moderen; en faders 
undertrykkende funktion overfor en 10-12-årig søn; voldsomhed mellem ægtefæller - og er det som noget på en gang sublimt-lystbetonetvisuelt og noget negativt lystbetonet, forbundet med oralitet (ufoerne ligner isvafler eller donaldburgers).

De to familieverdner mødes nu. Faderen kører rundt på mørke stier for at finde fejlen i el-forsyningen, i den sociale orden, og ser forst ikke det overnaturlige, ufoerne, der udover lys giver sig til kende som forskudte tegn på urscenen: En voldsom rysten, der făr postkasser og jernbaneoverskæringsudstyr til udtrykke kaos og sammenbrud. Dette ophidser faderen så meget at han kører efter ufoerne, på en sådan måde, at han er lige ved at køre 'den lille søn' ned (den lyst-drukne, den sublimt-grebne og den overjegsmanifesterende fader glider i ét). I sidste sekund făr han hæmmet sin udfoldelse, bremset bilen. Derved sker den forste forening af 'den nye kernefamilie', - den enlige mor, den lille dreng og 'faderen'. Denne moder er moderlig, på en gang grebet af omsorg for sønnen og 'åben', seksuelt set, overfor manden, markeret ved en V-udskæring i blusen. Familien bringes sammen i omsorg for barnet, ved kvindelig åbenhed og ved mandlig tilbageholdenhed. Autoritet-drift-problematikken forstærkes kort efter, da man forst ser de skinnende ufoer, derefter politibiler der i vild driftudfoldelse forfølger ufoerne og under denne 'lustige' autoritetsudfoldelse kører ud over en skrænt.

At volden og driftudfoldelsen udover at være mandlig også har forbindelse med amerikanskhed markeres ved et andet plan i filmen, hvor en videnskabsmand spillet af François Truffaut på et 'feminint' sprog (amerikansk med blød fransk accent eller direkte på fransk), forsøger at komme på sporet af ufoernes gåde ved hjælp af kunst og videnskab, men må spille sammen med det amerikanske militær der er grebet af voldsudfoldelsens eufori. Andetheden, fremmedheden giver sig dog yderst dobbelttydigt til kende: dels som en gigantisk kraft, der kan løfte et skib op fra havet til Gobi-ørkenen, dels som musik, som ulandsmennesker, børn og kunstner-videnskabsmænd har sans for. Kraftens dobbelthed ses eksplicit i den scene, som Monaco ikke kan forstå: Der blændes fra Truffauts musik-eftersøgning (disciplineret æstetik) til den lille drengs tilsvarende eksperimenter. Men drengens leder snart over i et 'helvede' der truer hele den lille intime mor-dreng-verden. Drengen går fascineret ud af huset i natten for at se de lystbetonede fænomener, hele ansigtet udtrykker infantil lyst. Moderen kommer og henter ham, spærrer huset af mod det fremmede, truende. Men et ildhav, forbundet med sammenbrud af den indre orden, vælter ind af alle sprækker og åbninger, trods moderens forgæves kamp. Sønnen vil have kontakt med de på en gang 
voldelige og sublime kræfter, og han vinder: da kræfterne er trængt ind i huset, flygter han ud, og, viser det sig senere, bliver taget op i rumskibet til ufoerne. Tidligere har vi set sønnen sidde og forsøge at bygge et falloslignende bjerg af jord.

Det første resultat af mødet med den store, sublime kraft har således ikke været positiv, den har forstærket opløsningen af familien. Mor-søn-dyaden er blevet opløst ved en 'indtrængende' vold, hidlokket af den lille dreng. Far-mor-pubertetsdrenge-triaden er blevet opløst p.gr.a. fadrens 'sygelige' optagethed af det socialt 'fortrængte', ufoer, der driver familien til indbyrdes vold (forstærket af moderens oprør), og medfører at moderen forlader hjemmet med sønnerne. Alle der har været nær 'kraften' er endvidere blevet 'mærket', har fået en sær solbrændthed.

$\mathrm{Nu}$ fortættes imidlertid den offentligt-sociale streng: ufoerne meddeler at de vil i kontakt med menneskene ved et højt bjerg i Wyoming. Militæret rydder området for mennesker ved at hævde at der er sket en kæmpeeksplosion af dødelig nervegas. For at frembringe illusionen giver de bl.a. masser af køer bedøvende indsprøjtninger, så de ligger ligagtige rundt $i$ landskabet. Myndighederne misbruger deres autoritet og stiller sig mellem menigmand og sandheden $/ \mathrm{kraften} / \mathrm{det}$ sublime. Neary, faderen, og Jillian Guiler, moderen, lader sig ikke skræmme; de er grebet af en vision, af det højere, og kæmper sig, trods myndighedernes forfølgelse, frem til bjerget. Og făr derfor første parket til et fantastisk show: ved hjælp af computerteknik og kunst (far og mor) etableres der i et orgiastisk lys-lyd-show, som i de bedste dage i 60erne, kontakt med det fremmede. Kæmperumskibet lander, og ud kommer dels en række amerikanske piloter, der har været forsvundet i årtier, dels den lille dreng, således at en ny kærnefamilie tilsyneladende ser ud til at kunne etableres. Men faderen er grebet af det højere, og fra at have været en social fallit, en bums midt i opløsningen af et hjem, bliver han nu en helgen-engel: Han bliver optaget blandt de astronautlignende amerikanere der frivilligt går ind i rumskibet for at gå til himmels, mens moder-søn betaget ser til. Det himmelsk fremmede er på en gang det teknisk-sublime og det barnligt-uskyldige; ufo-menneskene, der hersker over denne gigantiske teknik, er helt fosteragtigt nøgne og skrøbelige, hvorved det sublime samtidig bliver udtryk for at faderen giver sig ind under 'sønnens', forsonerens princip. Hele slut-sekvensen har tætte billedmæssige forbindelser dels selvfølgelig til en Disney-julestemning, dels til glansbilleder af Bethlehemagtige oplevelser. Kun ved underkastelsen under det sublime (filmen!) kan mennesket befriet for vold og driftbestemthed. 
Spielberg sammenvæver således to historier. Den forste kunne måske kort udskrives som 1 . Den tidlig-infantile maskuline seksualitet er en kraft der potentielt er et overgreb mod moderen. 2. Den faderlige magtudfoldelse har libidinøs karakter og truer såvel familieliv som forholdet mellem far og søn. Forudsætningen for sønnens og familiens befrielse er statueringen af dels en guddommelig fader, dels det uskyldigt-ømme barn der genopvækker moderfølelsen hos kvinden. Dette intime niveau integreres med et socialt, hvor myndigheder (og teknik) anklages for undertrykkelse, fordi de har mistet forbindelsen med de ømme og sublime værdier.

Dette fremgår tydeligere i Spielbergs næste film, tilskuerfiaskoen 1941-(1979). Filmen kostede en formue og havde karakter af parodi på et af Amerikas helligste krigsminder: situationen i 1941, hvor Japan overfalder USA. Filmen udspiller sig lige før dette angreb, og det første 'falliske' angreb er japansk: en nøgen kvinde 'spiddes' næsten på et japansk ubådsperiskop. Men hele filmen går ud på at vise at vold er »as american as apple pie«. Den ene paranoide amerikaner efter den anden forveksler andre amerikanere med fjenden, uafbrudt går de destruerende og hærgende løs på hinanden. Mest symbolsk i en situation hvor 'faderen' făr fat i en kæmpekanon, som nogle hjemmeværnsfolk har efterladt. Han ser dem imidlertid 'i deres spejlbillede' i ruden ind til hustruens sovekammer, hvor hun opholder sig i negligé. Han retter den gruelige kanon mod sovekammeret, hustruen undviger med nød og næppe, men hjemmet totalsmadres under den gevaldige kanons udfoldelse. Voldens sted er samtidig Hollywood, som det sted hvor voldsfantasierne forstærkes.

Den tætte sammenknytning af fallisk vold og sammenbrud af den patriarkalske orden er også temaet for E. T. (1983). En lille dreng bor sammen med sin ældre bror og moderen i et velhavende forstadsmiljø, men hjemmet er under opløsning, faderen har fundet en anden kvinde. Den spænding, der forårsages af det overjordiskes ankomst (Extra Terrestrial $=$ E. T.) sammenvaves med hjemmets opløsning, de unge drenges falliske udfoldelse og moderens fortvivlelse. Den lille dreng må tage sig af $\mathrm{E}$. T, et lille fosterlignende væsen, der er medlem af en kosmisk, økologisk ekspedition til frelse af truede plantearter. E.T. er på en gang extremt skrøbelig og ekstremt teknologisk magtfuld, og i forhold til den vilde udfoldelse bliver drengens forhold til E. T. etableringen af en moderlig-øm relation. Derved reddes det lille foster, og samtidig retableres senere den familiære tre-enighed, ved at en rummandslignende faderskikkelse kommer ind i hjemmet. 


\section{Postmoderne myte-og billedleg}

Spielbergs billedmæssige pragtværker som Raiders of the lost Ark (1981 efter idé af Lucas), Poltergeist (1982, formelt instrueret af Tobe Hooper) og Indiana Jones (1984) ekspliciterer og tildækker restaureringen af roller og familie ved på 'postmoderne' at være legende pasticher over fortidens adventure- og horror-produkter. I Indiana Jones bringes en lille kineserdreng, en kvinde-luder og en mand af landsknægttype sammen, og hver gang familien ikke kan enes, mest fordi kvinden ikke underkaster sig den mandlige autoritet, bringes dens medlemmer i fare. Poltergeist gennemspiller urscenefantasier for fuld udblæsning, hele forstadshjemmet er ved at gå under i illegitim udfoldelse. De sengerystende ånder kommer på én gang fra fortiden - ligene (traumerne) fra den gamle kirkegård hvorpå forstadsbebyggelsen er opført - og fra fjernsynet og dets fantasimæssige overstimulering. Da familien til sidst undslipper et hjem i ruiner og overnatter på et motel, sættes fjernsynet uden for døren.

Voldsomst iscenesættes den kønslige problematik i den smukke, sentimentale og slutteligt forsonende film The Colour Purple (1986) om en farvet kvindes liv i sydstaterne i begyndelsen af århundredet. Indledningens beskrivelse af de patriarkalske overgreb har en LéviStrauss-mytes ekstremisme: (Sted)faderen besvangrer ved flere lejligheder sin 'datter' med vold og river børnene væk fra hende direkte efter fødslen for at bortadoptere dem. Den patriarkalske drift fører både til 'for nære', incestuøse, og for 'fjerne' følelser, overklipning af mor-barn-dyaden. Senere bliver pigen bortgivet til en brutal mand og jordbesidder, og hundses som tjenestepige-hustru, skilles endda fra sit kæreste, sin søster. 'Hjælperen' bliver sublimering (hun lærer at læse og skrive), solidaritet - og kunst i form af en emanciperet ældre 'søster', der synger lystige sange i 20ernes og 30ernes jazz-liv, og som selv har lidt under patriarkalismen, i form af en streng baptist-præstefars forbandelse af lysten og 'kvinden'. Den undertrykte kvinde făr mod til oprør, forlader manden, forenes senere med sine børn, der ved uddannelse og ophold i Afrika har fået styrket deres sorte identitet, ligesom drift og pligt medieres i en stor scene, hvor kroens dansemusik og kirkens sang smelter sammen i lystfyldt spiritual, således at fader-patriarken og datteren forenes. Godheden i den sorte søstersolidaritet og moderfølelse kender ingen grænser, og den ustyrlige mandlige, egoistisk- kalkulerende ondskab ej heller; protesten er dog lidt en amerikansk 'forhistorie' der skal pege på integrationen af kvinden, den sorte, den socialt undertrykte i the American dream på basis af et allerede foretaget oprør og en allerede etableret forsoning af lyst og 
voldelig beherskelse i kunsten, the spiritual, i uddannelsen og i den æstetiske naturkontemplation. På nogle måder er Speilberg her, fra fotograferingen og dens stadige helt konkrete forankring i en barneøje-græsrodsposition til persontegning og budskab, meget romantisk $\mathrm{i}$ sin integrering af kvinde, sort og fattig i et tidligborgerligt sublimeringsforløb.

Mest legende, men samtidig mest eksplicit, behandles den ødipale problematik i filmen Back to the Future (1985). Miljøet er det sædvanlige forfaldne middle America, med en frusteret og hæmmet moder og en fader der er en social fiasko. Den 16-17-årige søn i huset har heldigvis en reservefader, en opfinder, der helt hengiver sig til sit grandiose jeg ved at opfinde tekniske vidundere. Han har opfundet en tids-bil, en bil der kan køre frem og tilbage i tiden (og som bl.a. er en metafor for filmens evne til tidsrejse). Baggrunden for at den unge mand kommer ud på en tidsrejse er tilsyneladende politisk: Da den 'guddommelige' onkel er ved at vise ham vidunderbilen ankommer nogle libyske terrorister (i et hippiekøretøj, et folkevognsrugbrød), som opfinderen har snydt for noget plutonium. De nedskyder ham, og den unge mand må flygte tilbage til fortiden, henover hippie-og-Vietnamamerika, til 1955, en 'uskyldig' tid, hvor USA var væsentligt mere landligt bornert, men samtidig også fri for terrorister. Indeklemtheden vises bl.a. i en scene hvor han, efter at have mødt sin far som yngling, overrasker denne, der med kikkert belurer den ungpigelige, fremtidige moders afklædning.

Desværre falder moderen for sønnen: I en ironisk kommentar til spørgsmålet om forførelsesteoriernes realitet, ser vi den fremtidige moder i en meget aktiv, ja næsten fortærende, jaws-agtig efterstræbelse af 'sønnen', som meget aktivt må arbejde imod at komme i seng med hende, og som med alle midler må iscenesætte at forældrene falder for hinanden, da han jo ellers må dø. Sønnen må arrangere en scene hvor moderen er den uskyldige skønhed der næsten bliver voldtaget af uhyret, og samtidigt kreere en rolle hvor faderen kan optræde som den ædle ridder, der redder skønheden og derved vinder hende. Tricket lykkes, moderens altfortærende begær efter sønnen overføres til en langt mere passiv lyst ved den nu ideale, mandige fader, hvilket bliver til begges fordel. Da sønnen, ved hjælp af en lynafleder (Benjamin Franklin, den teknisk/videnskabelige fader til den amerikanske drøm) kommer tilbage til Fremtiden, dvs. til Reagan-Amerika, har forældrenes langt bedre start i mellemtiden kreeret en total omvending. De er nu ikke forfaldne eksemplarer af underdog-America, men succesrige yuppier, begge selverhvervende med succes, med BMW, og 
en four-by-four pickup truck til sønnen. Man skulle næsten tro, at når blot man tager sig sammen, kan man gøre springet fra underhund til yuppie. Moralen er imidlertid at man selv og medieindustrien må konstruere de faderbilleder og overjegbilleder som ikke forefindes $\mathrm{i}$ virkeligheden.

Fortrængning og kønsrolle iscenesættes bevidst, elegantere må man sige end i Jaws. Den egentlige højrefløj bag Reagan, med rødder $i$ et vigende Amerika, drømmer om en sand tilbagevenden til fortiden og dens værdier. For det store centrum af USA der har stemt for Reagan og dyrket ham i popularitetsmålinger, er opslutningen mere partiel og filmisk. Opslutning omkring præstationsprincip, familie og traditionelt kønsrolle-spil, javel, men forenet med lige adgang til uddannelse og job for begge køn i en økologisk ansvarlig hi tech-verden, der fundamentalt bygger på en ikke-patriarkalsk individualisme. Den amerikanske historie i skikkelse af filmhistorien bliver et forrådskammer hvori man dykker ned for at hente både elementer til et postmoderne rollespil og styrke til fortrængning og idealisering. Fiktionen skal forsøge at gøre det arbejde, som hverken reklameindustri, familie eller skole rigtigt kan klare: At syntetisere lyst med præstation i en verden, hvor reklame og underholdning konstant sætter en gammeldags fortrængning ud af kraft og hvor den sociale myndighed svinger mellem utroværdighed og udvendig disciplin uden identifikatoriske egenskaber.

Det samlende begreb for alle de strømninger, der socialt peger opad er Hi Tech, med tilhørende mytologier. Lucas, Spielberg og 'lillebror' Badham, alle disse nye college-uddannede wiz kids, vidunderbørn, fremstiller ved selve deres filmiske udtryk og dolby stereolyd, drømmen om restaurationen af Amerika ved teknik. Væk er drømmen om tilbage til naturen, til dilettantismen og fattigdommen, kollektivet. Retningen er opad, mod teknisk stadigt mere raffinerede former for naturbeherskelse. Mange af de unge instruktørers film får derved teknik som både udtryk og indhold. Tressernes tekniske spøgelse var samlebåndet, stadig større teknisk-industrielle helheder, i forhold til hvilket enkeltindividet var objekt. Senhalvfjerdsernes og firsernes idol er PG'eren, State of the Art Technology i enkeltpersonens tjeneste, udviklet og produceret af små firmaer, der har en enkelt eller et lille team som stiftere, og forsynet med software af den lille, frie hacker, computer freak. Myten om Silicon Valley er myten om intelligensens store landnams- og pionertid, hvor stadigt mere jomfrueligt land tages i besiddelse. Myten om den unge 'special effect'-filmindustri med Lucas og Spielberg som wiz kids par excellence spejler Silicon Valley. Til Apple vs. IBM svarer Lucasfilm og Zoetrope vs. de 
gamle Hollywoodgiganter. Endda geografisk er der sammenfald: Silicon Valley ligger som bekendt i San Francisco-området, der også blev base for en række af de nye filmforetagender. Som universiterne blev industriens vækstcentre, således blev filmskolerne filmindustriens, - steder hvor f.eks. avanceret europæisk avantgardefilm-teknik kunne omdannes til en massefilm, der kan leve op til prædikatet State of the Art.

\section{En syntese af udfoldelse og social formning}

De billedmæssige og socialpsykologiske rammer om den fremadstormende socialgruppe, de højere intellektuelle mellemlag, hvorfra de nye helte rekrutteres, fortjener et nærmere eftersyn. At teknologi i PC-alderen forsynes med prædikatet 'Art', traditionelt et udtryk for en individuel og 'personlig' udfoldelse, peger mod en udvikling hvor arbejdslivet og dets produkter i stigende grad opleves som sublimeret lyst, som en syntese af det indre og det ydre, af id og overjeg. I slutningen af 60erne og begyndelsen af 70erne var det populært med en langt mere paranoid-skizoid iscenesættelse af teknikken og det intellektuelle arbejde. Principielt var teknikken forbundet med en næsten 1984'sk big brother overvågningsteknik, som i Pakula's The Parallax View fra året for Watergate-skandalens kulmination, 1974. For de finkulturelt ambitiøse tematiseredes (i forlængelse af europæiske film som Antonioni's Blow up), hvordan filmteknikken blev led i en sadistisk-voyeuristisk beherskelsesteknik der hurtigt kunne slå over i paranoia, oplevelser af konstant overvågning.

Coppola's Aflytningen fra 1974 er i nogle henseender typisk. Den lille intellektuelle, selvstændige ekspert $\mathrm{i}$ aflytning og $h i$ tech-aflytningsudstyr aflytter selv sin elskerinde, er helt fanget i en 'akustisk' voyeurisme. Han arbejder for en kæmpekorporation, tror at han medvirker til at opklare en forbrydelse, og opdager for sent at han blot medvirker til én (et mord på koncernpatriarken foretaget af lustige unge). Men samtidig bliver han nu selv genstand for overvågning, og han udvikler sig hurtigt i paranoid retning. Den hæmmede småborgers forlængelse af selvkontrol og teknisk selvrealisering i en sadistisk-voyeuristisk medmenneskekontrol adskiller sig ikke meget fra den futuristiske kæmpekoncerns menneskekontrol. Coppola kan endda noget af sin Freud: omslaget fra voyeurisme til paranoia foregår, da eksperten placerer sit lytteudstyr bag et toilet (analitet) for at belure, hvad han tror er Chef-'faderen's kones samleje med en anden/ 
yngre mand, mens det viser sig at hemmeligheden ikke er utroskab men mord på 'fader'-chefen. Untergang des Analcharakters! Den anale småborger ender med at totalsmadre sin kostbare, gammelborgerligt indrettede lejlighed i sin 'paranoide' jagt på skjulte mikrofoner. På tilsvarende måde var mange af højmodernisternes forhold til deres skrivearbejde sadistisk-voyeuristisk: jeg skriver, at jeg skriver, at jeg skriver - for nu at parodiere; forfattere og filmmagere overvågede sadistisk sig selv og deres skriveproduktion på samme måde som de i deres socialisationsproces havde følt sig overvåget af den anden/ de andre, de kafka'ske dommere. De skrivende giver, sat overfor disse dømmende andre, afkald på 'lystobjektet' til fordel for at tematisere deres blokering, deres inderliggjorte, sadistisk-voyeuristiske overjeg. Sanseligheden kommer til udtryk i blod og fragmentering.

I mange nyere film og videoer er den kontrollerende anden imidlertid ufortrengt tematiseret omkring de forskellige socialiserings-agenturer, fra lærernes sadisme til biblioteket med dets stramtandede, overvågende bibliotekar, læsesalens tavshedstvang m.v. Filmen Ghostbuster's (1984) beskrivelse af bibliotekstvangen (bl.a. i en fremstilling af et kæmpekartotek der totalt går bananas med omkringflyvende kort og skuffer) har således fundet mange efterlignere. F.eks. en engelsk musikvideo som på lydsiden har en ung mands sang, der udtrykker indestængt lyst. På billedsiden ses han i et bibliotek, beset af rædselsslagne og dømmende ordensrepræsentanter og en bibliotekarpige, med store briller og stramt hår. Kampen mellem lyst og overjeg bliver her helt konkret et forsøg på at erotisere den sociale institution, forandre overjegsmanifestanterne til lystobjekter, f.eks. ved at pigen løsner håret og aftager brillerne. Hans projekt kunne næsten karakteriseres ved melodien til Back to the Future: det er at demonstrere The Power of Love, at fortære indholdet af de sociale institutioner med hud og hår, for derved at komme til at besidde en uhæmmet grandios, social almagt. Tematiseringen af de overvågende øjne og institutioner sker slet ikke eller ikke primært med det formål at gøre oprør, men tværtimod for at integrere dem $\mathrm{i}$ identitetsdannelse og selvudfoldelse, på samme måde som mange rædselsfilm forsøger at integrere rædslerne i lysten.

Det har i adskillige hundrede år været den progressive pædagogiks formål at gøre indlæringen til en lystfyldt aktivitet. Ingen overvågende øjne, men derimod lystfyldt imitation; eleven der udvikler sig til homo ludens og realiserer sig selv i sin skaben. Den føromtalte PC, Apple, med det orale logo: kundskabens farvestrålende æble hvoraf man roligt og uden syndsbevidsthed kan tage en bid, ser vidensoptagelse som en lystfyldt oral inkorporering. Manualen til dens tekstpro- 
gram har som første øvelsessætning: »A penny earned isn't much «. En kort og lidt nedslående sætning. Men allerede næste sætning fremviser den lystfyld te orale inkorporering som vejen til lærdom: »I love pizza smothered in tomato sauce, onions, olives, chilies, mushrooms, and bell peppers, topped with cheese and anchovies, then followed by something light for dessert - chocolate cake, perhaps«. Den lange madorgasme vil endda ingen ende tage, den ender i det frie, suggestive 'perhaps'. Man lærer nu at skrive overskrifter: »My Favorite Snack «, at indskyde en forsætning: »Any time of the day or night, I love pizza ...« Skriveprocessen skal ikke som for de overjegs-spolerede være drevet frem af det overvågende øje, der kontrollerer den verbale afføring (jeg skriver, at jeg skriver), men være munter fortæring, stræben mod objektet, spejlet, skærmen.

Filmen Wargames (1983) tegner portrætter af denne muntre intellektualisme. Her må en computerfreak søge om hjælp til et problem. Først går han gennem et kæmpe kontorlandskab med tonsvis af antiseptisk udseende mainframe-computerudstyr, elektronikkens svar på samlebåndet. Derefter kommer han ind $\mathrm{i}$ et lille, rodet baglokale, hvor computerkunstnerne, genierne sidder. De skildres som narcissistiske indtil det patologiske, jaloux, og svingende mellem aggression og ekstrem venlighed. Men de kan kanalisere deres narcissisme ind $\mathrm{i}$ arbejdet, de kan ophidses over vanskelige problemer, hektisk besætte det indtil det er løst. Temaet er velkendt: Den halvgale, narcissistiske men geniale videnskabsmand og kunstner, der 'fortærer' og inkorporerer verden til privat, intellektuel manipulation, på samme måde som barnet, der får stillet små legetøjsmodeller af fly, biler osv. til sin rådighed. For barnet repræsenterer originalerne den gigantiske Anden, og det kan kun optræde som subjekt for denne grandiositet når det foreligger i en symbolsk, miniaturiseret version, der imidlertid følelsesmæssigt besidcier originalens grandiositet og andethed. På tilsvarende vis kan intellektet inkorporere og lege med verden. Overjeget er libidinøst besat.

Som pædagogisk projekt kan man se denne lystige, ludiske indlæring som en tilnærmelse mellem pædagogikken og reklamen. For selvfølgelig er reklame ( $\mathrm{g}$ anden samfundsmæssig eufori) i sin funktion ikke den blotte lyst. Reklamen skulle gerne vakke behovet for en vare, et tilfredsstillelsesobjekt, og ved at fremmane et lystobjekt påpeger den en mangel ved modtageren, der jo ikke er i besiddelse af objektet (selvom euforien bl.a. består i det glade budskab om at man kan fă en sådan genstand). Reklamen besidder således også et sublimerende aspekt: den fremviser noget fraværende, som den opfordrer modtageren til at stræbe efter, den river modtageren ud af umiddel- 
barheden til fordel for middelbare lystgevinster. Reklamen er derfor korrekt doseret $\mathrm{i}$ forhold til individets muligheder - en gevaldig sensualisering af udskydelse og præstation, umiddelbarhedens lystfyldte underkastelse under middelbarheden. Adorno gjorde den interessante, omend ikke helt korrekte iagttagelse at jazzens rytmer mimede samlebåndenes mekaniske fungeren, hvad der fyldte ham med småborgerlig gru. Gruen kom måske fra rytmens markering af sammenhæng mellem lyst og socialitet, fremmedbestemthed. Det interessante består i at se den mediebårne underholdningsindustri og den rigtige 'industri' som aspektualiseringer af samme samfundsmæssiggørelse og ikke som polære modsætninger (f.eks. underholdning som 'virkelighedsflugt'). Medierne er i den forstand His Master's Voice: samfundstotaliteten, dens evigt-fremmede rytme og driftudskydelse miniaturiseret som subjektiv udfoldelse og nærvær; radioens musikalske 'I Need You', er både sårets åbning og dets sutur. Denne syntese af lyst og arbejde kan, i en lidt luvslidt udgave, ses i Las Vegas' endeløse haller af enarmede tyveknægte, hvor folkepensionister fra Los Angeles i timevis næsten robotagtigt passer de farvestrålende maskiner på de slidte tæpper; hvis de er hurtige kan de passe tre-fire stykker, fodre med mønter, trække, fodre, trække.

Den foromtalte film Wargames, der er instrueret af John Badham, er en næsten idealtypisk iscenesættelse af den lystige intellektualisme. Her bearbejdes forestillingen om restaureringen af præstationsprincippet og patriarkalismen, svejset sammen med den lystfyldte, næsten kinetisk-reklameagtige selvudfoldelse og inkorporering af den sociale grandiositet. Plottet er tilsyneladende en remake af Dr. Strangelove. Da det viser sig at den menneskelige faktor forhindrer personalet i våbensiloerne $\mathrm{i}$ at affyre de interkontinentale atomraketter, forsynes de med relæer og er således direkte underlagt en kæmpecomputer WOPR (navnet minder om den kendte burger-variant), kun et par affyringskoder står mellem maskine og raketter. Vi ser 'Det store billede', kæmpesamfundet med dets gevaldige teknik, raketter, lastbiler, sikkerhedskoder, dets enorme kommandocentraler, den komplekse arbejdsdeling.

Snart er vi imidlertid i 'det lille billede': en ung mand vil hverken underkaste sig et hierarkisk-smalsporet skolesystem eller sine bornerte forældre; han kaster hele sin kærlighed på computeren, som han bruger al sin energi på. Den giver ham grandios almagt; han sætter den f.eks. til at kalde alle telefonnumre i Sunneyvale (i Silicon Valley) for at finde telefonnummeret på en spilfabrikant, men får i stedet kontakt med ledningen til hovedcomputeren for den vestlige verdens krigsmaskineri - alt mens hans pige beundrende betragter hans al- 
magt, hvis narcissistiske karakter senere understreges i billeder af dataskærmen, der spejler hans ansigt. WOPR tilbyder en menu af forskellige spil, fra det uskyldige skak til det mindre uskyldige Total Thermonuclear War, som han ikke kan komme til at spille fordi han ikke kender koden. Tanken om at komme til at spille det vanskelige spil bliver nu en total besættelse, der făr ham til at forsøge at bryde koden døgnet rundt; han skulker fra skolen, glemmer alt omkring sig og sidder med bar overkrop under sine forgæves forsøg. Aktiviteten er på den ene side den rene lystudfoldelse, spillelidenskab, men på den anden side også et sublimeringsforløb; drengen indordner sig fuldt under et større mål. Aktiviteten er en illustration af det intellektuelle arbejdes narcissistiske karakter (jfr. min Sherlock Holmes-analyse i Lystmord).

Det viser sig at kodens hemmelighed ligger i den patriarkalske relation mellem fader og søn. Drengen får det råd at efterspore hemmeligheden i 'faderens', i spillets ophavsmand, dr. Falken's privatliv. Drengen drives ud i efterforskning, han opsøger biblioteker, kikker på mikrofiche og endda på video-optagelser af ophavsmanden. Endelig henledes hans opmærksomhed på at dr. Falken nærede ømme følelser til sin søn, hvis navn Joshua netop - elementært, min kære Watson er koden til den uhyggelige 'spillemaskine'. Han løser gåden sammen med sin pige, og delvis ved hendes hjælp, men det karakteristiske ved hans aktivitet er netop dens sublimerende karakter; han udskyder kropslige behov til fordel for åndelige; kontakten med dobbeltheden af lyst/spil og over-jeg/arbejde/'fader'. Men motiveringen til arbejdet er den progressive pædagogiks 'vidensbegær', lysten til at inkorporere det almægtige spil, ikke pligt.

Da 'faderen' er inkorporeret ved at gåden, 'sønnens navn', er løst, vender billedet imidlertid: arbejdet slår nu over i 'storhedsvandvids'lust, der potentielt truer med den totale objektdestruktion/objektinkorporation: drengen og pigen beslutter sig til - under lystig softdrinkindtagelse - at prøve spillet Total Thermonuclear War, endda på russernes side. Pigen hepper ham til at forstærke den falliske aggressivitet, de sender diverse raketter, fly og ubådsbaserede raketter mod deres hjemby og mod Las Vegas, spillets, syndens og lystens by, dvs. mod totaliten af ømme og sanselige størrelser. Men hvad de tror bare er 'for sjov' træder frem på den store skærm, i det store billede: i hovedkvarteret tror man i mange minutter at der er et angreb igang, for skærmen viser hvad de unge mennesker taster ind. Først da drengen kaldes bort, forsvinder illusionerne fra skærmen. Men spillet er sat i gang, maskinen fortsætter spillet, og har til hensigt at spille det til ende og realisere det i 'virkeligheden', aktivere raketterne. Drengen 
arresteres, konfronteres med det sociale overjeg, der har opdaget hans tilbøjeligheder for 'spil'. Eftersom myndighedsrepræsentanterne selv spiller farlige spil, ophidses derved, og har tillid til teknikken udenfor dem selv, tror de straks at drengen er agent for russerne og overhører hans advarsler om at teknikken er ved at løbe løbsk. Drengen må nu, med pigens hjælp, opsøge maskinens 'far', Dr. Falken, ja endda genopvække ham fra de døde (han er, i sorg over sin søns og konens død i en færdselsulykke, holdt op med at arbejde og er af sikkerhedsgrunde blevet erklæret død). Faderen er på den ene side en darwinist, der passivt tror på tilværelseskampen, og samtidig en moralist, der tror at menneskeheden har dømt sig selv til døden. Men drengen og pigen genopliver hans følelse af ansvar, og de overbeviser i fælleskab de militære og politiske myndigheder om at det er teknikken, maskinerne, spillet der giver en illusion af angreb, krig og aggressivitet, - ikke russerne. Nu kommer imidlertid drengens store tour de force. Maskinen nægter at adlyde ordren om ikke at affyre raketterne og forsøger i lyntempo at finde affyringskoderne for at fuldføre spillet. Med barnets blanding af genialitet og simpelhed sætter drengen den til at spille kryds og bolle, der altid ender uafgjort, for at maskinen derved kan lære, at der $\mathrm{i}$ atomkrig ikke kan blive nogen vindere. $\mathrm{Og}$ - oh, mirakel - maskinen lærer og stopper affyringen.

Tilsyneladende er filmen en advarsel mod teknikken, men hele dens fremtoning er én lang tilbedende fremstilling af avanceret teknologi som lystfyldt almagtsfigur. Budskabet er kontrol: af affyringsprocedurer, af jeg-et. Filmen er optaget under opvarmningsfasen til Reagans stjernekrigsprojekt, og dens holdning er tydeligvis en anden end hans, den er uparanoid i forhold til russerne, dens budskab er de intellektuelle mellemlags: get involved, take a stand. Den fundamentale udvikling på det karaktereologiske plan er etableringen af forbindelsen mellem 'sønnen' og 'faderen' $i$ en gensidig læreproces, hvor 'faderen' lærer noget om følelser, mens 'sønnen' lærer sublimeringens, intellektualismens og udskydelsens vanskelige kunst, lærer at bøje sin lystfulde spilletrang ind under realitetsprincippet. Og dog: han stopper krigsspillet som han startede det, ved udfoldelsen af grandiosgenial, teknisk legelyst, der inkorporerer selv klodens redning fra død og undergang, dvs. det absolutte 'over-jeg', døden, i sin lystfyldte udfoldelse. Udstyret med en PC eller en WOPR er ikke engang stjernerne grænsen.

Det glade budskab om det arbejdende-legende menneske, om sammensmeltning af kunst og teknik som forskellige former for individuel selvudfoldelse udtrykker såvel et ideologisk udsagn som en mere be- 
grænset og socialt specifik sandhed om yuppie-Amerika. De dele af ungdomsoprøret, der i from rousseau-isme erstattede konstruktion og naturbeherskelse med mystisk naturkontemplation og en idealistisk søgen mod en oprindelig menneskenatur som skulle genopstå ved en relativ simpel dekonstruktion af 'systemet' og en pjalteproletarisk bricolage i dets porer, kan forekomme unødigt defaitistiske. Leden ved civiliseringsprocessen der forkortet næsten blev synonym med 'fremmedgørelse' i en lidt romantisk forestilling om et oprindeligt, arbejdsløst og uproduceret selvnærvær, blev til tider en ny variant af syndefaldsmyten. Når renaissancen for den lystfyldte naturbeherskelse som selvudfoldelse skal ske i Reagan-Amerikas 'unødigt' hierarkiske uddannelsessystem og erhvervsliv og nærmest som alternativ til den nedslidte offentligt-civile sektor skal det måske ses på baggrund af sentressernes ulyst ved at reformere institutionerne til fordel for drømmen om en fundamental revolution, en radikal småborgerliggørelse af produktion i tusindvis små produktionskollektiver. Tilsvarende på produktsiden: jo mere genstandene viste hen til det 'håndværksmæssige' enkeltindivids 'menneskelige' dilettantisme des bedre, jo mere de repræsenterede det arbejdsdelte, samarbejdende samfunds professionalisme, dets glitrende, perfektionistiske kollektivt-anonyme kunnen, des værre, des mere var de udtryk for en uhuman 'varefetichisme' og teknokratisme. Det var som om kollektiv professionalisme og privatkapitalisme var to alen af samme stykke. Kultur-og vækstoptimisme var næsten forpagtet af det private erhvervsliv, og genkomsten af fascinationen ved den 'sublime' identifikation med den kollektive og monumentale udfoldelse var derved næsten hjemfalden til at foregå i et privatkapitalistisk regie.

Ligesom myten om den grænseløse naturbeherskelse var også myten om den dynamisk-euforiske selvudfoldelse forpagtet af de kommercielle kræfter. Da den kontemplative flipper blev midaldrende, blev han jogger, forsøgte i det små at opøve selvkontrollens og selvovervågningens gammelmodige kunst. Motorisk udfoldelse er lidelse, åndens stadige kropsdrab. Jogging'en er derved et modbillede til sports-euforien, drømmen om en lystfyld syntese af den totale motoriske kropsudfoldelse med artistisk selvkontrol. Sporten bliver i denne forstand myten om det narcissistiske selvnærvær ved kontrollens inkorporation i lysten og ved fremstilling af en næsten objektløs, usplittet selvudfoldelse. Denne rendyrkede og tilsyneladende objektløse narcissisme finder man i den kinetiske annonce, dvs. en annonce, hvor man ser (især unge) mennesker i voldsom, euforisk bevægelse, hvor deres subjektivitet og deres narcissisme går op i en højere enhed. De har allerede inkorporeret produktet: det sår som den sædvanlige 
reklames ' $\mathrm{du}$ behøver $\mathrm{X}$ ' normalt forvolder, er næsten usynligt. De står på ski, vandski, skateboard, de surfer, springer, danser etc. som udtryk for den eufori og kraftfuldhed som det pågældende produkt bibringer dem. I en central scene i Back to the Future ser man således den ungdommelige helt udfolde sig i al sin almagt på skateboard til stor forbløffelse for 50er-ungdommen. Luftcykleturen i $E$. T. er en tilsvarende ekstrem almagtsfantasi (og en uhyre lukrativ product placement for en japansk cykelfabrik). Udlændinge der iagttager den amerikanske mediekultur og ungdomskultur kan fascineres af den hensynsløshed, hvormed der fremstilles sådanne euforiske almagtsfantasier og af det omfang, hvori man fremstiller de samfundsmæssige potenser som inkorporerede i enkeltindividets udfoldelse.

Surfin'-Cruisin'-USA var i Lucas' American Grafitti (1973), - retrofilmen par excellence - en fortidig figur som skulle tjene til at give styrke i underkastelse under præstationsprincippet, objektbesætningen. I Stephen King's roman Christine og filmatiseringen heraf (1984), fremstilles fascinationen af cruisin'-America, af fallisk narcissisme, udfoldet i en ung mands besathed af en kromskinnende veteranbil, som udtryk for en pirrende, men dæmonisk og farlig asocialitet. En Lasch eller en Marcuse ville forfærdet rynke brynene over den kinetiske narcissisme og den vareeuforiske cruisin' og måske foretrække jogger'en, der dog har erindringen om et overjeg, selvom det kun kan bruges til selvdisciplinering og dermed til tvangsmæssig tilpasning til en hierarkisk storbyjungle. Jeg har andetsteds (i Melankoliens Potens, K \& K nr. 56) beskrevet hvorledes euforiseringen af den varesamfundsmæessige og 'kinetiske' subjektivitet i 80'erne med Miami Vice (som allerede i American Grafitti) er indskrevet i melankoliens irrealitet. Den dynamisk-euforiske selvudfoldelse har karakter af en begrundende myte og billedverden, der løsriver udfoldelsen fra den binding til jorden, redskabet, kønsobjektet, vi kender fra Westernmytologi eller by-krimi, til fordel for den 'selvbærende', narcissistiske abstrakthed, der er nødvendig i det postmoderne samfund. Narcissisme er blevet et skældsord, et ord til beskrivelse af dysfunk tion, bl.a. i skrifter fra intellektuelle, der dag efter dag med lyst miniaturiserer verden og kun bearbejder den i det omfang den optræder som bevidsthedsspor i deres hjerner. David Riesmann's bog om Det ensomme massemenneske var en af de forste beskrivelser af overgangen fra det 19. århs. »indrestyrede« karakterer med de stive normer og det faste over-jeg, til de »andre-styrede«, "other-directed " personer, der foretager en fortsat fleksibel tilpasning til deres omgivelser. Mange læste bogen som en forherligelse af fortidens indrestyrede karakterer. Det var for dem bedre med personer, der var blevet programmeret én 
gang for alle under lidelse, end personer der fortløbende blev programmeret med lyst. Reklame, forlystelsesindustri, varefetichen, hele den massive symbolproduktion der kontinuerligt binder enkeltindividet sammen med samfundstotaliteten opfattes som en større fremmedstyring end éngangsprogrammeringen (og som en énvejskommunikation, indoktrinering, ikke som en kompleks social interaktion og bevidstgorelse). Kun feticheringen af den stille, dannede narcissistiske besætning af læsningen af 'den gode bog' var unddraget den generelle fordømmelse. Riesman's egen holdning var imidlertid betydeligt mere nuanceret, og i forordene til 1961-og 1969-udgaverne tager han eksplicit afstand fra de læsninger af bogen, der ser bort fra dens kritik af en række aspekter ved den indrestyrede karakter, ligesom han understreger de civilisatoriske fremskridt, der ligger i »other-directedness «. I de konkluderende afsnit af bogen arbejder Riesman selv med det utopiske begreb mautonomi«, et forsøg på at forene nogle aspekter af indrestyring og "other-directedness" $\mathrm{i}$ kombination med en mere legende tilgang til virkeligheden end de foregående socialtypers med deres afhængighed af barndommens eller omverdenens programmering.

Indrestyring var engang adelsmærket for det intellektuelle mellemlag, men dets store vækst $\mathrm{i}$ de seneste årtier er faldet sammen med en generel svækkelse af den type hårdhændet afkald og fortrængning, der tidligere kendetegnede dets medlemmer, uden at deres præstationsevne er blevet væsentligt nedsat heraf. Præstationen styres nu blot efter gulerodens mere end efter stokkens principper, lystbilleder fortættes med præstationsbilleder og overvågningsbilleder. I en vis forstand er disse individer mindre 'narcissistiske' end de indrestyrede karakterer, for hvem såvel kilderne til deres fascinationer som deres stærke libidinøse besætning af over-jeget var fortrængt og satte sig igennem bagom ryggen på dem; hos de 'moderne' typer er fascinationsobjekternes og præstationslystens kilder ikke fortrængt, men indsuges og bindes til stadighed $\mathrm{i}$ arbejdets og forlystelsens kulturelle mønstre. I firsernes mediebilleder har vi set en æstetiseret og libidinøs revival af analkarakteren, hyppigt netop som f.eks. hos Spielberg taget ud af filmarkiverne, med jakkesæt og navy-cut, som et særligt rollespil af samme type som når lønmodtagere leger Tarzan o.l. i fritidslandskabet. Denne revival er selvfølgelig en tilpasning til de skærpede præstationskrav, de fortløbende evalueringer, - men en mere lystfyldt tilpasning: man 'leger' analkarakter for kortere eller længere tidsrum, man 'regrederer' periodisk til den, i en libidinøs besættelse af den type man finder i Wargames. Man kan selvfølgelig se fænomenet som en 'prøvebesætning' som en overgang til den fulde 
identifikation af samme art som når børn legende besætter de voksnes adfærd.

Men i denne fase er adfærden situationsbestemt, fleksibel, hvad en række apologeter for 'jeg-styrke' (der i mange sammenhænge blot er et finere ord 'over-jegstyring' eller 'indre-styring') finder negativt, selvom man lige så godt kan se fleksibel interaktion med givne betingelser som udtryk for en langt mere rationel adfærd der er sig de faktorer, der påvirker den, bevidst. Det er for intellektuelle kulturradikale let at forveksle socialiseringsbetinget fortrængning med jegstyrke, og fleksibilitet med holdningsløs tilpasning. I dagens Amerika forekommer en række 'indrestyrede' grupperinger, politiske og religiøse fundamentalister, mere skræmmende end 'attituderelativisterne'.

\section{USA i Post-Reaganismens epoke?}

Politisk og økonomisk er USA ved at foretage en langstrakt og smertelig tilpasning til en situation, hvor det kun er ét af adskillige højindustrielle mega-områder, ved siden af Vesteuropa, Sydøstasien og delvis Østeuropa. De vigende socialgrupper fastholder stadig, og på stadig mere desperat vis, den voldelige imperialisme og individualisme som grundlaget for den kulturelle identitet. Rambo'ismen kan samle fulde huse i biograferne. Dynasty fremviser med lyst en verden, hvor alles kamp mod alle skaber den bedst tænkelige af alle verdener, i det mindste findes der ikke bedre, mere attraktive alternativer til en på en gang darwinistisk og patriarkalsk opfattet storkapitalisme. Økonomisk har USA foretaget et for hurtigt spring ind i 'postindustrialismen'; ideologer som Daniel Bell m.fl. har endda tilsløret at den nye samfundsorden - kommunikations- og servicesamfundet - ikke er nedlæggelsen af industrisamfundet, men tværtimod dets nye gennembrud, hvad Japans satsning på ingeniører fremfor sagførere og børsspekulanter er et vink om. Afbygningen af de spæde elementer til socialforsorg har varet ledsaget af darwinistisk-nietzscheansk hoveren over det stivnet-blødsødne og alderdomssvækkede Europa, der ikke evnede en brutal iscenesættelse af tilværelseskampen - selvom der til gengæld er en række tikkende sociale bomber under guds eget fædreland.

Yuppie-amerika har ganske vist været fellow-traveller til Reagan og den småborgerlige neo-darwinisme, men det er vanskeligt at forestille sig at rejsen kan vedblive med at være lige gnidningsfri. Den pludseli- 
ge eskalering af kampen mod apartheid i foråret 1986 med udbredte demonstrationer og konfrontationer på alle campus'er var en minirevival af 60erne, og Reagan-styrets delvise kapitulation demonstrerede frygten for at gamle og nye radikale alliancer skulle komme til live. Amerikanske videnskabsmænds massive modstand mod stjernekrigsprojektet er et andet tegn på latenser. 60ernes oprør var imidlertid i mange henseender en kulturrevolution, hvis sociale side gik imod udviklingen af produktivkræfterne fremfor at ville styre dem. En ny radikalisme er imidlertid mere sandsynlig som led i såvel en kulturel som en materiel modernisering. 60ernes 'kulturrevolution' har bidraget til en opløsning og mediering af modsætningen mellem massekultur og elitekultur i forlængelse af de sociale forskydninger og har ajourført det kærnefamiliære liv og de højere mellemlags mentale udstyr. Reaganismens fallit og overvindelsen af oliekrisetraumet behøver ikke nødvendigvis at blive opsuget $i$ rambo'isme, men kan tværtimod åbne op for ny social og kulturel eksperimenterelyst. Back to the Future's tidsrejsende bevæger sig tilbage til 1950erne på atomkraft, frem til nutiden ved Franklins lyn-afleder, men foretager også en rejse ind i fremtiden, hvad der gør vidunderbilen til futuristisk økologi: den kan nu gå på skrald, på genbrug, med lynets kromskinnende fart. Nutidens voldsomme genbrug og nybrug af historiens billeder, stilarter og forestillinger er, sådan set, ikke led i forfald og barbarisk sammenhængsløs dekonstruktionisme, men led i en ny optimistisk global konstruktionisme.

\section{Litteratur}

Tony Crawley: The Steven Spielberg story, (1983).

Torben Kragh Grodal: »Sherlock Holmes« in Holmgaard og Michaelis, ed.: Lystmord, 1984.

Cohen, Mast: Film theory and criticism (1985).

James Monaco: American Film Now (1979).

Bill Nichols: Ideology and the image. (1981).

Bill Nichols ed.: Movies and methods I-II (1976, 1985).

Dale Pollock: The life and films of George Lucas (1983).

Kaare Schmidt: "John Badham og teknikkens vidundere» in Kosmorama 166.

Robin Wood: Hollywood from Vietnam to Reagan (1986).

David Riesman: The Loneley Crowd (1950, 1961). 